\title{
TNFAIP8 variants as potential epidemiological and predictive biomarkers in ovarian cancer
}

Hongyu Gao ${ }^{1}$, Zhiran Zhang ${ }^{2}$, Liangliang Jiang ${ }^{2}$, Lei Zhang ${ }^{3}$, Ling Qin ${ }^{4}$, Tianbo Liu ${ }^{*^{*}} \mathbb{D}$ and Shanshan Yang ${ }^{5^{*}}$

\begin{abstract}
Background: This research aimed to investigate the association between tumor necrosis factor-a-induced protein 8 (TNFAIP8) polymorphisms and ovarian cancer (OC) susceptibility.

Methods: A case-control study of 210 patients with $O C$ and 231 healthy controls was conducted to assess the association between TNFAIP8 polymorphisms (rs 1 1064, rs 1045241, and rs 1045242) and OC risk in Heilongjiang Province of China. The SNaPshot SNP assay was conducted to detect SNP genotype. Logistic regression analysis was applied to illustrate the underlying association.

Results: Our research found that TNFAIP8 rs 11064 and rs 1045242 were significantly connected with the susceptibility of OC. Additionally, rs 1045242 increased the risk of OC, while rs 11064 performed a protective role in the risk of OC. Data revealed that rs 1045242 strongly related with advanced FIGO stage, larger residual tumor, and the presence of recurrence.

Conclusions: TNFAIP8 genetic variants, which may play difference roles, were significantly associated with OC susceptibility. The underlying molecular mechanism needs be clarified with scientific evidence.
\end{abstract}

Keywords: TNFAIP8 polymorphism, Ovarian cancer, Susceptibility, rs1 1064, rs1045242, Predictive biomarkers, Recurrence

\section{Background}

More than 3000 women a year were diagnosed ovarian cancer $(\mathrm{OC})$ and two third of them ultimately die in the next 5 years $[1,2]$. Furthermore, the incidence and mortality of Chinese women with OC has increased significantly [3]. However, no worthily diagnostic methods worldwide were applied for early detection of OC resulting in that $\mathrm{OC}$ were more common in advanced clinical stages [2]. Regarding that OC is a multigenic disease [4,

\footnotetext{
*Correspondence: skyliu_1030@163.com; dr_yss@126.com

${ }^{2}$ Department of Gynecology, Harbin Medical University Cancer Hospital,

Harbin Medical University, 150 Haping Road, Harbin 150081, China

${ }^{5}$ Department of Gynecological Radiotherapy, Harbin Medical

University Cancer Hospital, Harbin Medical University, 150 Haping Road, Harbin 150081, China

Full list of author information is available at the end of the article
}

5], the influence of environmental on its pathogenesis should not be neglected [6]. Therefore, it may be an interesting option to investigate key genes and their interaction with the environment for prevention and treatment of OC.

Tumor necrosis factor-a-induced protein 8 (TNFAIP8), as well as a TNF $\alpha$-inducible gene in endothelial cells [7], was localized at chromosome 5 in the forward strand q23 region $[8,9]$. TNFAIP8 takes part in the process of apoptosis and autophagy in different types of cells. Overexpression of TNFAIP8 is frequently observed in malignant tumors $[8,10-20]$, that is significantly correlated to excessive proliferation, reduced apoptosis, enhanced invasion and metastasis, and drug resistance. Polymorphisms of TNFAIP8 gene are reported to be associated with risks of different cancers $[9,14,21]$. Additionally, we

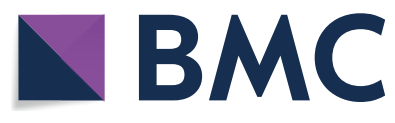

(c) The Author(s) 2020. This article is licensed under a Creative Commons Attribution 4.0 International License, which permits use, sharing, adaptation, distribution and reproduction in any medium or format, as long as you give appropriate credit to the original author(s) and the source, provide a link to the Creative Commons licence, and indicate if changes were made. The images or other third party material in this article are included in the article's Creative Commons licence, unless indicated otherwise in a credit line to the material. If material is not included in the article's Creative Commons licence and your intended use is not permitted by statutory regulation or exceeds the permitted use, you will need to obtain permission directly from the copyright holder. To view a copy of this licence, visit http://creativecommons.org/licenses/by/4.0/. The Creative Commons Public Domain Dedication waiver (http://creativecommons.org/publicdomain/zero/1.0/) applies to the data made available in this article, unless otherwise stated in a credit line to the data. 
have demonstrated that elevated expression of TNFAIP8 protein implies poor prognosis and is related with resistance of OC $[13,22,23]$. However, there were no existing findings regarding the relationship of TNFAIP8 polymorphisms with OC risks. Therefore, we aimed to clarify the connection between TNFAIP8 polymorphism and OC susceptibility among people in Heilongjiang Province of China.

\section{Materials and methods} Subjects and blood samples

Totally 210 OC patients and 231 contemporaneously healthy individuals were recruited from the Harbin Medical University Cancer Hospital between September 2015 and February 2017. All OC cases were classified and evaluated according to the International Federation of Obstetricians and Gynecologists (FIGO) [24]. The pathological type was diagnosed as epithelial OC which contained serous, mucinous, endometrioid, and clear cell histological type. Exclusion criteria: (1) Any of the recruited patients who received preoperative chemo-, radio- or immunotherapy; (2) any control subject with malignant tumor or digestive disease, or the family history of any cancers; (3) incomplete clinical case data or incomplete follow-up information. Peripheral blood samples $(5 \mathrm{~mL})$ were collected from all subjects at the time of hospital admission.

The distributions of clinical data of all subjects are shown in Table 1 . The study protocol was approved by Harbin Medical University Cancer Hospital Committee (ethical number: KY2019-09) and all subjects provided signed informed consent from patients and controls.

\section{Genotyping}

Peripheral blood $(5 \mathrm{ml}$ ) from each subject was sampled in vacuum tubes with $5 \%$ ethylene diamine tetraacetic acid (EDTA). Then genomic DNA from whole blood was extracted using a blood genomic DNA extraction kit (Axygen Biotechnology, Union City, CA, USA) according to the manufacturer's instruction and stored at $-20{ }^{\circ} \mathrm{C}$ for genotyping by polymerase chain reaction (PCR). Three TNFAIP8 SNPs (rs11064, rs1045241, and rs1045242) were selected in the present study according to our previous study [21], and we used Primer Blast to design the PCR amplification primers as follows: The PCR mixture contained $100 \mathrm{ng}$ of genomic DNA, $4 \mu \mathrm{l}$ of $2.5 \mathrm{mM}$ dNTP, $10 \mu \mathrm{l}$ of PCR buffer, $10 \mu \mathrm{M}$ of upstream and downstream primers, $1 \mu \mathrm{l}$ each, $0.5 \mathrm{U}$ of PrimeSTAR HS DNA polymerase (TAKARA, DALIAN, China) in a $50-\mu l$ reaction volume. The PCR amplification conditions were: $94{ }^{\circ} \mathrm{C}, 5 \mathrm{~min}, 35$ cycles; $98^{\circ} \mathrm{C}, 10 \mathrm{~s} ; 58^{\circ} \mathrm{C}, 15 \mathrm{~s}$; $72{ }^{\circ} \mathrm{C}, 2 \mathrm{~min}$, final extension step, $72{ }^{\circ} \mathrm{C}, 5 \mathrm{~min}$. Then, the SNaPshot SNP assay was conducted to detect SNP

\begin{tabular}{|c|c|c|c|}
\hline Characteristics & Cases & Controls & $P^{*}$ \\
\hline Age & $53.24 \pm 10.54$ & $54.32 \pm 9.58$ & 0.261 \\
\hline BMI & $25.40 \pm 3.65$ & $25.47 \pm 3.52$ & 0.814 \\
\hline \multicolumn{3}{|c|}{ Family cancer history (ovarian cancer) } & \multirow[t]{3}{*}{0.023} \\
\hline No & 203 & 230 & \\
\hline Yes & 7 & 1 & \\
\hline \multicolumn{3}{|l|}{ Parity } & \multirow[t]{3}{*}{0.415} \\
\hline Nulliparity & 32 & 29 & \\
\hline Multiparity & 178 & 202 & \\
\hline \multicolumn{3}{|l|}{ Complication $^{\mathrm{a}}$} & \multirow[t]{3}{*}{0.060} \\
\hline No & 158 & 155 & \\
\hline Yes & 52 & 76 & \\
\hline \multicolumn{3}{|l|}{ Smoking history } & \multirow[t]{3}{*}{0.583} \\
\hline No & 159 & 180 & \\
\hline Yes & 51 & 51 & \\
\hline \multicolumn{4}{|l|}{ FIGO stage } \\
\hline$|/| \mid$ & \multicolumn{3}{|l|}{94} \\
\hline III/IV & \multicolumn{3}{|l|}{116} \\
\hline \multicolumn{4}{|l|}{ Histologic grade } \\
\hline $\mathrm{G} 1 / \mathrm{G} 2$ & \multicolumn{3}{|l|}{95} \\
\hline G3 & \multicolumn{3}{|l|}{115} \\
\hline \multicolumn{4}{|l|}{ Histological type } \\
\hline Serous & \multicolumn{3}{|l|}{132} \\
\hline Mucinous & \multicolumn{3}{|l|}{31} \\
\hline Endometrioid & \multicolumn{3}{|l|}{32} \\
\hline Clear cell & \multicolumn{3}{|l|}{15} \\
\hline \multicolumn{4}{|c|}{ Residual tumor size } \\
\hline$\leq 1 \mathrm{~cm}$ & \multicolumn{3}{|l|}{132} \\
\hline$>1 \mathrm{~cm}$ & \multicolumn{3}{|l|}{78} \\
\hline \multicolumn{4}{|l|}{ Ascites } \\
\hline$\leq 100 \mathrm{ml}$ & \multicolumn{3}{|l|}{64} \\
\hline$>100 \mathrm{ml}$ & \multicolumn{3}{|l|}{146} \\
\hline \multicolumn{4}{|l|}{ Serum CA-125 level } \\
\hline$\leq 35 \mathrm{U} / \mathrm{ml}$ & \multicolumn{3}{|l|}{45} \\
\hline$>35 \mathrm{U} / \mathrm{ml}$ & \multicolumn{3}{|l|}{165} \\
\hline Recurrence & & & \\
\hline No & 124 & & \\
\hline Yes & 86 & & \\
\hline
\end{tabular}

BMI body mass index, FIGO the Federation of Gynaecology and Obstetrics, G1 Well differentiated, $G 2$ moderately differentiated, $G 3$ poorly differentiated

* Two-sided Chi squared test or Fisher's text or student's t text

a Complication: patients with diabetes and cardio-cerebrovascular disease

genotype. The GeneMapperTM 4.0 Software (Applied Biosystems, Foster City, CA, USA) was applied to analyzed the resulting data. About $5 \%$ of the specimens were chosen randomly and genotyped twice to ensure the genotyping accuracy: the reproducibility was 100\% [21]. 


\section{Statistical analysis}

All statistical analyses were performed with SPSS 22.0 (SPSS, Chicago, Illinois, USA). Genotype and allele distributions were assessed and the chi-square test was used to evaluated the Hardy-Weinberg equilibrium among the controls. Continuous variables were presented using mean \pm SD and statistically analyzed using t-test. Categorical variables were statistically analyzed using the chisquare test or Fisher's text. The crude odds ratio (COR), adjusted odds ratio (AOR), and 95\% confidence interval (CI) of logistic regression analysis was calculated in four genetic models (allele, co-dominant, dominant, and recessive) to assess the association between TNFAIP8 single nucleotide polymorphisms (SNPs) and OC susceptibility with adjustment for age, smoking history, complication, and family history. All tests were two-tailed and $P<0.05$ was considered statistical significance.

\section{Results}

Demographic characteristics the of study population The connection between TNFAIP8 SNPs and OC risk was explored in Heilongjiang Province of China. The basic information of all individuals was summarized in Table 1. The average ages of cases and controls were $53.24 \pm 10.54$ and $54.32 \pm 9.58$ years, respectively. Furthermore, no significant difference was observed between these two groups $(P=0.261)$. Also, there was no significant difference of body mass index (BMI) between two groups $(P=0.814)$. In addition, there were no significant differences between the cases and controls in Parity, complication and smoking history $(P>0.05)$. However, positive significance $(P=0.023)$ between the case and control groups was presented in family cancer history (ovarian cancer).

\section{The relationship of TNFAIP8 polymorphism with OC risk}

In this case-control study, three SNPs (rs11064, rs1045241, and rs1045242) which are located in the $3^{\prime}$ UTR, which is a binding site for the regulation of gene expression by microRNAs (miRNAs) in TNFAIP8 gene were selected and analyzed [21]. The genotype frequencies of each SNP conformed to the Hardy-Weinberg equilibrium among controls $(P>0.05$ for all). Displayed in Table 2, TNFAIP8 rs11064 A-allele (COR: 0.690, 95\% CI 0.491-0.971, $P=0.033$ and AOR: $0.709,95 \% \mathrm{CI}$ 0.504-0.997, $P=0.048$ ) and rs1045242 G-allele (COR: $1.619,95 \%$ CI $1.129-2.323, P=0.009$ and AOR: 1.628 , $95 \%$ CI 1.132-2.342, $P=0.009$ ) are risk factors for OC. However, the allele of TNFAIP8 rs1045241 had no effect on the risk of OC $(P>0.05)$.

For further examination, we conducted the correlation between the genotypes of SNPs and OC risk by logistic regression analysis under the codominant, dominant, and recessive models (Table 3). Our results showed that rs11064 was significantly associated with increased OC susceptibility in codominant model (GG/ AA, COR: $0.200,95 \%$ CI $0.057-0.706, P=0.012$ and AOR: $0.205,95 \%$ CI $0.058-0.726, P=0.014)$ and recessive model (GG/AA + AG, COR: 0.209 , 95\% CI 0.060 $0.731, P=0.014$ and AOR: 0.212 , 95\% CI $0.060-0.744$, $P=0.016)$. Also, we demonstrated that rs1045242 was related to a higher risk of $\mathrm{OC}$ under codominant model (AG/AA, COR: 1.670, 95\% CI 1.091-2.558, $P=0.018$ and AOR: $1.703,95 \%$ CI 1.108-2.618, $P=0.015)$ and dominant model (AG+GG/AA, COR: 1.736, 95\% CI 1.149-2.623, $P=0.009$ and AOR: $1.761,95 \%$ CI $1.162-$ $2.670, P=0.008)$. However, there was no significant association between TNFAIP8 rs1045241 and OC risk.

Table 2 The distribution of allele frequencies of TNFAIP8 SNPs in cases and controls

\begin{tabular}{|c|c|c|c|c|c|c|}
\hline Variables & $\begin{array}{l}\text { Cases (\%) } \\
n=420\end{array}$ & $\begin{array}{l}\text { Controls (\%) } \\
n=462\end{array}$ & COR $(95 \% \mathrm{Cl})$ & $P$ & AOR $(95 \% \mathrm{Cl})$ & $P^{*}$ \\
\hline \multicolumn{7}{|l|}{ rs11064 } \\
\hline A & $352(83.8)$ & $361(78.1)$ & 1.000 & & 1.000 & \\
\hline G & $68(16.2)$ & $101(21.9)$ & $0.690(0.491-0.971)$ & 0.033 & $0.709(0.504-0.997)$ & 0.048 \\
\hline \multicolumn{7}{|l|}{ rs1045241 } \\
\hline C & $341(81.2)$ & $372(80.5)$ & 1.000 & & 1.000 & \\
\hline$T$ & $79(18.8)$ & $90(19.5)$ & $0.958(0.684-1.340)$ & 0.800 & $0.960(0.684-1.349)$ & 0.816 \\
\hline \multicolumn{7}{|l|}{ rs1045242 } \\
\hline A & $337(80.2)$ & $401(86.8)$ & 1.000 & & 1.000 & \\
\hline G & 83 (19.8) & $61(13.2)$ & $1.619(1.129-2.323)$ & 0.009 & $1.628(1.132-2.342)$ & 0.009 \\
\hline
\end{tabular}

COR crude odds ratio, $A O R$ adjusted odds ratio, $\mathrm{Cl}$ confidence interval

* Data were calculated by logistic regression, adjusted for age, smoking history, complication, family history 
Table 3 Relationship of TNFAIP8 polymorphisms and ovarian cancer risk

\begin{tabular}{|c|c|c|c|c|c|c|}
\hline Variables & $\begin{array}{l}\text { Cases }(\%) \\
n=210\end{array}$ & $\begin{array}{l}\text { Controls (\%) } \\
n=231\end{array}$ & COR $(95 \% \mathrm{Cl})$ & $P$ & AOR $(95 \% \mathrm{Cl})$ & $P^{*}$ \\
\hline \multicolumn{7}{|l|}{ rs11064 } \\
\hline \multicolumn{7}{|c|}{ Codominant } \\
\hline $\mathrm{AA}$ & $145(69.0)$ & $145(62.8)$ & 1.000 & 0.040 & 1.000 & 0.048 \\
\hline$A G$ & $62(29.5)$ & $15(6.5)$ & $0.873(0.579-1.317)$ & 0.518 & $0.905(0.598-1.370)$ & 0.636 \\
\hline GG & $3(1.4)$ & & $0.200(0.057-0.706)$ & 0.012 & $0.205(0.058-0.726)$ & 0.014 \\
\hline \multicolumn{7}{|l|}{ Dominant } \\
\hline $\mathrm{AA}$ & $145(69.0)$ & $145(62.8)$ & 1.000 & & 1.000 & \\
\hline $\mathrm{AG}+\mathrm{GG}$ & $65(31.0)$ & $86(37.2)$ & $0.756(0.509-1.123)$ & 0.166 & $0.782(0.524-1.165)$ & 0.226 \\
\hline \multicolumn{7}{|l|}{ Recessive } \\
\hline $\mathrm{AA}+\mathrm{AG}$ & 207 (98.6) & $216(93.5)$ & 1.000 & & 1.000 & \\
\hline GG & $3(1.4)$ & $15(6.5)$ & $0.209(0.060-0.731)$ & 0.014 & $0.212(0.060-0.744)$ & 0.016 \\
\hline \multicolumn{7}{|l|}{ rs1045241 } \\
\hline \multicolumn{7}{|c|}{ Codominant } \\
\hline CC & $137(65.2)$ & $154(66.7)$ & 1.000 & 0.276 & 1.000 & 0.214 \\
\hline$C T$ & $67(31.9)$ & $64(27.7)$ & $1.177(0.779-1.778)$ & 0.440 & $1.216(0.801-1.846)$ & 0.359 \\
\hline $\mathrm{TT}$ & $6(2.9)$ & $13(5.6)$ & $0.519(0.192-1.402)$ & 0.196 & $0.497(0.183-1.350)$ & 0.170 \\
\hline \multicolumn{7}{|l|}{ Dominant } \\
\hline CC & $137(65.2)$ & $154(66.7)$ & 1.000 & & 1.000 & \\
\hline $\mathrm{CT}+\mathrm{TT}$ & 73 (34.8) & 77 (33.3) & $1.066(0.718-1.581)$ & 0.752 & $1.089(0.731-1.622)$ & 0.674 \\
\hline \multicolumn{7}{|l|}{ Recessive } \\
\hline $\mathrm{CC}+\mathrm{CT}$ & $204(97.1)$ & $218(94.4)$ & 1.000 & & 1.000 & \\
\hline $\mathrm{TT}$ & $6(2.9)$ & $13(5.6)$ & $0.493(0.184-1.322)$ & 0.160 & $0.468(0.174-1.263)$ & 0.134 \\
\hline \multicolumn{7}{|l|}{ rs1045242 } \\
\hline \multicolumn{7}{|c|}{ Codominant } \\
\hline AA & $135(64.3)$ & $175(75.8)$ & 1.000 & 0.026 & 1.000 & 0.025 \\
\hline$A G$ & $67(31.9)$ & $52(22.5)$ & $1.670(1.091-2.558)$ & 0.018 & $1.703(1.108-2.618)$ & 0.015 \\
\hline GG & $8(3.8)$ & $4(1.7)$ & $2.593(0.765-8.791)$ & 0.126 & $2.490(0.731-8.484)$ & 0.145 \\
\hline \multicolumn{7}{|l|}{ Dominant } \\
\hline $\mathrm{AA}$ & $135(64.3)$ & $175(75.8)$ & 1.000 & & 1.000 & \\
\hline$A G+G G$ & 75 (35.7) & $56(24.2)$ & $1.736(1.149-2.623)$ & 0.009 & $1.761(1.162-2.670)$ & 0.008 \\
\hline \multicolumn{7}{|l|}{ Recessive } \\
\hline $\mathrm{AA}+\mathrm{AG}$ & $202(96.2)$ & $227(98.3)$ & 1.000 & & 1.000 & \\
\hline GG & $8(3.8)$ & $4(1.7)$ & $2.248(0.667-7.576)$ & 0.191 & $2.151(0.635-7.286)$ & 0.218 \\
\hline
\end{tabular}

COR crude odds ratio, $A O R$ adjusted odds ratio, $\mathrm{Cl}$ confidence interval

* Data were calculated by logistic regression, adjusted for age, smoking history, complication, family history

Stratification analysis between TNFAIP8 SNPs and OC risk based on age, smoking history, complication, and family history

Aiming to deeply analyze the relationships of TNFAIP8 genotypes with OC susceptibility, we divided age into $\leq 54$ years old and $>54$ years old, whether smoking, whether complication (patients with diabetes and cardio-cerebrovascular disease), and whether there is family history of OC. It revealed that rs1045242 mutation (AG+GG/AA) would significantly increase risk of OC (OR: 2.048, 95\% CI 1.116-3.757, $P=0.021$ ) at age $\leq 54$ years old (Additional file 1 : Table S1). In subjects with no smoking history, the rs11064 mutation (GG) was a protective factor for OC (OR: 0.164, 95\% CI 0.036-0.742, $P=0.019)$. On the contrary, the rs1045242 mutation (AG+GG) was a risk factor for OC (OR: 2.670, 95\% CI 1.141-6.247, $P=0.024$ ) in subjects with smoking history (Additional file 1: Table S2). As showed in Additional file 1: Tables S3 and S4, the rs1045242 mutation (AG+GG) was a risk factor for OC in subjects with no complication (OR: $1.829,95 \%$ CI $1.109-3.018, P=0.018)$ and no family history of OC (OR: 1.746, 95\% CI 1.150-2.650, $P=0.009$ ). The rs11064 GG genotype was a protective factor for OC in 
subjects with no family history of OC (OR: $0.205,95 \%$ CI 0.058-0.724, $P=0.014$ ).

\section{Correlation between TNFAIP8 SNPs and clinicopathological characteristics of $\mathrm{OC}$}

The correlation between three TNFAIP8 genotypes and the clinicopathologic data of $\mathrm{OC}$ is illustrated in Table 4. It was found that rs 1045242 was related to an increased risk in OC patients with III/IV FIGO stage ( $P=0.040$ and $P=0.013$, respectively) and presence of recurrence $(P=0.043$ and $P=0.034$, respectively) both under codominant and dominant models. For rs1045242, it was confirmed that AG + GG genotype was significantly associated with an increased OC risk in residual tumor more than $1 \mathrm{~cm}(P=0.019)$. rs1045241 SNP was strongly significant associated with FIGO stage $(P=0.025)$ and residual tumor $(P=0.033)$ under dominant model. Furthermore, rs11064 SNP was observed to be positively related to FIGO stage both under codominant $(P=0.024)$ and dominant $(P=0.006)$ models.

\section{Discussion}

In present study, we found that TNFAIP8 polymorphisms (rs11064 and rs1045242) were significantly associated with OC susceptibility. Furthermore, the GG-genotype of rs11064 was a protective factor and the AG + GG-genotype of rs1045242 was a risk factor for OC susceptibility. In addition, TNFAIP8 rs1045242 gene polymorphism was linked to advanced FIGO stage, larger residual tumor, and the presence of recurrence in OCs. Taken together, our current findings provided an crucial role of TNFAIP8 gene in the occurrence of OC, thus may give evidence on the potentially functional SNPs in TNFAIP8 and their clinical outcomes in OC patients.

TNFAIP8 polymorphism has been recently investigated in several disease including solid human cancer (cervical cancer and endometrial cancer) and Non-Hodgkin's Lymphoma (NHL) which indicates that SNPs are the most common type of genetic variations caused by the heterogeneity among various types of human cancer $[9$, $14,21]$. Recent research suggests that genetic polymorphisms play a crucial role in the pathogenesis of OC [2527]. To our knowledge, we illuminated the association

Table 4 The association between TNFAIP8 polymorphisms and clinicopathological characteristics of ovarian cancer

\begin{tabular}{|c|c|c|c|c|c|c|c|c|c|c|c|c|c|c|c|}
\hline \multirow[t]{2}{*}{ Characteristics } & \multicolumn{4}{|c|}{ rs11064 } & \multirow[t]{2}{*}{$P^{*}$} & \multicolumn{4}{|c|}{ rs1045241 } & \multirow[t]{2}{*}{$P^{*}$} & \multicolumn{4}{|c|}{ rs1045242 } & \multirow[t]{2}{*}{$P^{*}$} \\
\hline & $A A$ & AG & GG & $A G+G G$ & & $\mathrm{CC}$ & $\mathrm{CT}$ & $\mathrm{TT}$ & $\mathrm{CC}+\mathrm{CT}$ & & $A A$ & AG & GG & $A G+G G$ & \\
\hline FIGO stage & & & & & 0.024 & & & & & 0.082 & & & & & 0.04 \\
\hline$|/| \mid$ & 74 & 19 & 1 & 20 & 0.006 & 69 & 23 & 2 & 25 & 0.025 & 69 & 23 & 2 & 25 & 0.013 \\
\hline III/IV & 71 & 43 & 2 & 45 & & 68 & 44 & 4 & 48 & & 66 & 44 & 6 & 50 & \\
\hline Histologic grade & & & & & 0.862 & & & & & 0.827 & & & & & 0.894 \\
\hline $\mathrm{G} 1 / \mathrm{G} 2$ & 67 & 27 & 1 & 28 & 0.674 & 63 & 30 & 2 & 32 & 0.766 & 62 & 30 & 3 & 33 & 0.788 \\
\hline G3 & 78 & 35 & 2 & 37 & & 74 & 37 & 4 & 41 & & 73 & 37 & 5 & 42 & \\
\hline Histological type & & & & & - & & & & & - & & & & & - \\
\hline Serous & 89 & 40 & 3 & 43 & 0.463 & 86 & 40 & 6 & 46 & 0.446 & 81 & 40 & 8 & 48 & 0.43 \\
\hline Mucinous & 22 & 9 & - & 9 & & 21 & 10 & - & 10 & & 21 & 10 & - & 10 & \\
\hline Endometrioid & 21 & 11 & - & 11 & & 18 & 14 & - & 14 & & 18 & 14 & - & 14 & \\
\hline Clear cell & 13 & 2 & - & 2 & & 12 & 3 & - & 3 & & 12 & 3 & - & 3 & \\
\hline Residual tumor & & & & & 0.28 & & & & & 0.098 & & & & & 0.064 \\
\hline$\leq 1 \mathrm{~cm}$ & 86 & 44 & 2 & 46 & 0.112 & 79 & 49 & 4 & 53 & 0.033 & 77 & 49 & 6 & 55 & 0.019 \\
\hline$>1 \mathrm{~cm}$ & 59 & 18 & 1 & 19 & & 58 & 18 & 2 & 20 & & 58 & 18 & 2 & 20 & \\
\hline Ascites & & & & & - & & & & & 0.739 & & & & & 0.508 \\
\hline$\leq 100 \mathrm{ml}$ & 46 & 18 & - & 18 & 0.557 & 43 & 20 & 1 & 21 & 0.694 & 43 & 20 & 1 & 21 & 0.561 \\
\hline$>100 \mathrm{ml}$ & 99 & 44 & 3 & 47 & & 94 & 47 & 5 & 52 & & 92 & 47 & 7 & 54 & \\
\hline Serum CA-125 & & & & & 0.800 & & & & & 0.573 & & & & & 0.69 \\
\hline$\leq 35 \mathrm{U} / \mathrm{m}$ & 32 & 12 & 1 & 13 & 0.736 & 31 & 12 & 2 & 14 & 0.562 & 31 & 12 & 2 & 14 & 0.467 \\
\hline$>35 \mathrm{U} / \mathrm{ml}$ & 113 & 50 & 2 & 52 & & 106 & 55 & 4 & 59 & & 104 & 55 & 6 & 61 & \\
\hline Recurrence & & & & & 0.071 & & & & & 0.112 & & & & & 0.043 \\
\hline No & 93 & 30 & 1 & 32 & 0.437 & 88 & 33 & 3 & 38 & 0.086 & 88 & 33 & 3 & 36 & 0.034 \\
\hline Yes & 52 & 32 & 2 & 23 & & 49 & 34 & 3 & 35 & & 47 & 34 & 5 & 39 & \\
\hline
\end{tabular}

FIGO the Federation of Gynaecology and Obstetrics, G1 well differentiated, G2 moderately differentiated, G3 poorly differentiated

* Two-sided chi-squared test or Fisher's text 
between TNFAIP8 polymorphism and OC risk for the first time.

In cervical cancer, it revealed that the GG genotype of TNFAIP8 rs11064 was connected with an elevated risk compared with AA/AG genotypes [14]. Furthermore, the study of endometrial cancer (EC) [21] showed that the GG genotype and AG + GG genotype of TNFAIP8 rs11064 were both associated with increased risk compared with controls. However, our present research found that the G allele and GG allele of TNFAIP8 rs11064 both played a reduced role in risk of OC (AOR: 0.709; 95\% CI 0.504-0.997 for G allele and AOR: 0.205; 95\% CI 0.0580.726 for GG allele). The discordance of the above findings may be explained by that the effect of genetic factors often differs in different individuals.

No considerable relationship between TNFAIP8 rs1045241 and OC risk was identified in our present paper. Additionally, our previous study in EC had been in accordance with this result [21]. Searching from the literature data, TNFAIP8 rs1045241 polymorphism was reported to have clinical significance in no other reports except that in NHL. Zhang et al. [9] demonstrated that the polymorphism of TNFAIP8 rs1045241 may lead to NHL susceptibility in a Chinese population. We believe that the related role of environmental factors may not be ignored. So far, no literature except our team has reported the relationship between TNFAIP8 rs1045242 polymorphism and tumor. Our results showed that TNFAIP8 rs1045242 G allele carriers showed increased risk of OC by 1.628 times compared to the A allele carriers. Also, the AG + GG genotype of TNFAIP8 rs1045242 increased 1.761 times risks of OC compared with AA genotype. These findings were consistent with previous study in EC [21]. The above provide evidence that TNFAIP8 rs1045242 polymorphism may involve in the onset of gynecological malignancy.

Besides, subgroup analysis revealed that TNFAIP8 rs1045242 polymorphism increased the risk of OC in patients with age $\leq 54$ years old, smoking history, no complication, and no family cancer history, uncovering that individuals exposed to these factors are more susceptible to OC. In patients with no smoking history and no family cancer history, the GG allele of TNFAIP8 rs11064 SNPs played a protective factor for OC. However, the underlying mechanism that the same genotype performs opposite effects in different tumor types remains to be illuminated.

Moreover, we explored the connection between the TNFAIP8 genes polymorphism and clinical variables of OC. We suggested that TNFAIP8 genes polymorphism (rs11064, rs1045241, and rs1045242) were significantly connected with FIGO stage. In addition, TNFAIP8 rs1045242 polymorphism was also strongly associated with residual tumor, and recurrence, indicating its role of progression in OC. For rs11064, it was reported that it positively linked to deep myometrial invasion and lymph node metastasis under the codominant model in ECs [21]. In cervical cancer, it attempted to explore the relationship between TNFAIP8 rs11064 polymorphism and drug resistance, but with no sense [14]. The association between TNFAIP8 rs1045242 polymorphism and stage in NHL was observed [9].

The present study is the first to explore TNFAIP8 variants and susceptibility in OC, however, it has come limitations. For example, the follow-up period was not sufficiently long, and our study was retrospective and included a relatively small number of Chinese patients form a single center. Thus, future examination of large sample size and multiple centers are needed to verify genotype-phenotype associations and functional analysis for TNFAIP8 SNP.

\section{Conclusion}

This study suggests that TNFAIP8 rs11064 and rs1045242 polymorphisms are remarkably linked with the risk of OC in Heilongjiang Province of China. However, the GG allele of TNFAIP8 in the two genotypes played the opposite roles in the risk of OC. Furthermore, we found that TNFAIP8 rs1045242 polymorphism had an effect on clinical significance of FIGO stage, residual tumor, and recurrence, indicating its progressive role in OC. Yet, there are some limitations and shortcomings. Whether TNFAIP8 rs1045242 polymorphism affected the protein expression status and its effect on prognosis remain to unclear. It is well-known that the inherited mutations of BRCA1 and BRCA2 genes resulted in hereditary breast and ovarian cancer syndrome (HBOC). However, there are only 7 of 210 OC patients have OC family history and only 1 of $210 \mathrm{OC}$ patients have HBOC in the present case-control study. Thus, well-designed larger including patients with $\mathrm{HBOC}$ and hereditary nonpolyposis colon cancer (HNPCC), prospective study with functional analysis is an interesting direction and deserves further study which would give some new insights in the molecular mechanism of OC occurrence.

\section{Supplementary information}

Supplementary information accompanies this paper at https://doi. org/10.1186/s12935-020-01490-7.

Additional file 1: Table S1. Stratified analysis between TNFAIP8 polymorphisms and ovarian cancer risk by age. Table $\mathbf{S 2}$. Stratified analysis between TNFAIP8 polymorphisms and ovarian cancer risk by smoking history. Table S3. Stratified analysis between TNFAIP8 polymorphisms and ovarian cancer risk by complication. Table $\mathbf{S 4}$. Stratified analysis between TNFAIP8 polymorphisms and ovarian cancer risk by family history. 


\section{Acknowledgements \\ Not applicable.}

\section{Authors' contributions}

TBL and HG conceived and designed the study. LLJ and ZRZ collected samples and processed data. LQ and LZ provided technical support. SSY analyzed data. TBL drafted the manuscript. SSY revised the manuscript. All authors read and approved the final manuscript.

\section{Funding}

This study was supported by grants the Youth Elite Training Foundation of Harbin Medical University Cancer Hospital (JY2016-03), the Key Projects of Haiyan Foundation of Harbin Medical University Cancer Hospital (JJZD201902) and Outstanding Youth Programme of Harbin Medical University Cancer Hospital (JCQN2019-06)

\section{Availability of data and materials}

All data generated and analyzed during this study are included in this published article and its additional file.

\section{Ethics approval and consent to participate}

The current study was approved by the Ethics Committee of Harbin Medical University Cancer Hospital (ethical number: KY2019-09). A written consent from each participant was obtained after they were informed the purpose of this study.

\section{Consent for publication}

Not applicable.

\section{Competing interests}

The authors declare that they have no competing interests.

\section{Author details}

${ }^{1}$ Department of Gastroenterologic Surgery, Harbin Medical University Cancer Hospital, Harbin Medical University, Harbin 150081, China. ${ }^{2}$ Department of Gynecology, Harbin Medical University Cancer Hospital, Harbin Medical University, 150 Haping Road, Harbin 150081, China. ${ }^{3}$ Department of Ultrasound, Harbin Medical University Cancer Hospital, Harbin Medical University, Harbin 150081, China. ${ }^{4}$ Department of Pathology, Harbin Medical University Cancer Hospital, Harbin Medical University, Harbin 150081, China. ${ }^{5}$ Department of Gynecological Radiotherapy, Harbin Medical University Cancer Hospital, Harbin Medical University, 150 Haping Road, Harbin 150081, China.

\section{Received: 17 May 2020 Accepted: 10 August 2020}

Published online: 17 August 2020

\section{References}

1. Miller KD, Siegel RL, Lin CC. Cancer treatment and survivorship statistics, 2016. CA Cancer J Clin. 2016;66(4):271-89.

2. Wojciechowska U, Didkowska J, Zatonski W. Corpus uteri cancer. In: Zatonski W, editor. Cancer in Poland in 2006. Warsaw: Department of Epidemiology and Cancer Prevention; 2008. p. 30-2.

3. Huang Z, Zheng Y, Wen W, Wu C, Bao P, Wang C, Zhong W, Gao YT, Jin F, Xiang YB, Shu XO, Beeghly-Fadiel A. Incidence and mortality of gynaecological cancers: secular trends in urban Shanghai, China over 40 years. Eur J Cancer. 2016;63:1-10.

4. Jones MR, Kamara D, Karlan BY, Pharoah PDP, Gayther SA. Genetic epidemiology of ovarian cancer and prospects for polygenic risk prediction. Gynecol Oncol. 2017;147(3):705-13.

5. Kar SP, Berchuck A, Gayther SA, Goode EL, Moysich KB, Pearce CL, Ramus SJ, Schildkraut JM, Sellers TA, Pharoah PDP. Common genetic variation and susceptibility to ovarian cancer: current insights and future directions. Cancer Epidemiol Biomarkers Prev. 2018:27(4):395-404.

6. Pearce CL, Rossing MA, Lee AW, Ness RB, Webb PM, Chenevix-Trench G, Jordan SM, Stram DA, Chang-Claude J, Hein R, Nickels S, Lurie G, Thompson PJ, Carney ME, Goodman MT, Moysich K, Hogdall E, Jensen A, Goode EL, Fridley BL, Cunningham JM, Vierkant RA, Weber RP, Ziogas A, AntonCulver H, Gayther SA, Gentry-Maharaj A, Menon U, Ramus SJ, Brinton L,
Wentzensen N, Lissowska J, Garcia-Closas M, Massuger LF, Kiemeney LA, Van Altena AM, Aben KK, Berchuck A, Doherty JA, Iversen E, McGuire V, Moorman PG, Pharoah P, Pike MC, Risch H, Sieh W, Stram DO, Terry KL, Whittemore A, Wu AH, Schildkraut JM, Kjaer SK, for Australian Cancer Study (Ovarian Cancer), Australian Ovarian Cancer Study Group, Ovarian Cancer Association Consortium. Combined and interactive effects of environmental and GWAS-identified risk factors in ovariancancer. Cancer Epidemiol Biomarkers Prev. 2013;22(5):880-90.

7. Horrevoets AJ, Fontijn RD, van Zonneveld AJ, de Vries CJ, Ten Cate JW, Pannekoek $\mathrm{H}$. Vascular endothelial genes that are responsive to tumor necrosis factor-alpha in vitro are expressed in atherosclerotic 1 esions, including inhibitor of apoptosis protein-1, stannin, and two novel genes. Blood. 1999;93(10):3418-31.

8. Li Y, Jing C, Chen Y, Wang J, Zhou M, Liu X, Sun D, Mu L, Li L, Guo X. Expression of tumor necrosis factor a-induced protein 8 is upregulated in human gastric cancer and regulates cell proliferation, invasion and migration. Mol Med Rep. 2015;12(2):2636-42.

9. Zhang $Y$, Wang MY, He J, Wang JC, Yang YJ, Jin L, Chen ZY, Ma XJ, Sun MH, Xia KQ, Hong XN, Wei QY, Zhou XY. Tumor necrosis factor-a induced protein 8 polymorphism and risk of non-Hodgkin's lymphoma in a Chinese population: a case-control study. PLoS ONE. 2012;7(5):e37846.

10. Kumar D, Gokhale P, Broustas C, Chakravarty D, Ahmad I, Kasid U. Expression of SCC-S2, an antiapoptotic molecule, correlates with enhanced proliferation and tumorigenicity of MDA-MB 435 cells. Oncogene. 2004;23(2):612-6.

11. Hadisaputri YE, Miyazaki T, Suzuki S, Yokobori T, Kobayashi T, Tanaka N, Inose T, Sohda M, Kuwano H. TNFAIP8 overexpression: clinical relevance to esophageal squamous cell carcinoma. Ann Surg Oncol. 2012;19(Suppl 3):S589-96.

12. Liu K, Qin CK, Wang ZY, Liu SX, Cui XP, Zhang DY. Expression of tumor necrosis factor-alpha-induced protein 8 in pancreas tissues and its correlation with epithelial growth factor receptor levels. Asian Pac J Cancer Prev. 2012;13(3):847-50.

13. Liu T, Gao H, Chen X, Lou G, Gu L, Yang M, Xia B, Yin H. TNFAIP8 as a predictor of metastasis and a novel prognostic biomarker in patients with epithelial ovarian cancer. Br J Cancer. 2013;109(6):1685-92.

14. Shi TY, Cheng X, Yu KD, Sun MH, Shao ZM, Wang MY, Zhu ML, He J, Li QX, Chen XJ, Zhou XY, Wu X, Wei Q. Functional variants in TNFAIP8 associated with cervical cancer susceptibility and clinical outcomes. Carcinogenesis. 2013;34(4):770-8.

15. Zhang C, Kallakury BV, Ross JS, Mewani RR, Sheehan CE, Sakabe I, Luta G, Kumar D, Yadavalli S, Starr J, Sreenath TL, Srivastava S, Pollard HB, Eidelman O, Srivastava M, Kasid UN. The significance of TNFAIP8 in prostate cancer response to radiation and docetaxel and disease recurrence. Int J Cancer. 2013;133(1):31-42.

16. Liu T, Gao H, Yang M, Zhao T, Liu Y, Lou G. Correlation of TNFAIP8 overexpression with the proliferation, metastasis, and disease-free survival in endometrial cancer. Tumour Biol. 2014;35(6):5805-14.

17. Yang M, Zhao Q, Wang X, Liu T, Yao G, Lou C, Zhang Y. TNFAIP8 overexpression is associated with lymph node metastasis and poor prognosis in intestinal-type gastric adenocarcinoma. Histopathology. 2014;65(4):517-26.

18. Dong Q, Fu L, Zhao Y, Xie C, Li Q, Wang E. TNFAIP8 interacts with LATS1 and promotes aggressiveness through regulation of Hippopathway in hepatocellular carcinoma. Oncotarget. 2017;8(9):15689-703.

19. Xiao M, Xu Q, Lou C, Qin Y, Ning X, Liu T, Zhao X, Jia S, Huang Y. Overexpression of TNFAIP8 is associated with tumor aggressiveness and poor prognosis in patients with invasive ductal breast carcinoma. Hum Pathol. 2017;62:40-9.

20. Xing Y, Liu Y, Liu T, Meng Q, Lu H, Liu W, Hu J, Li C, Cao M, Yan S, Huang J, Wang T, Cai L. TNFAIP8 promotes the proliferation and cisplatin chemoresistance of non-small cell lung cancer through MDM2/p53 pathway. Cell Commun Signal. 2018;16(1):43.

21. Liu T, Jiang L, Yu L, Ge T, Wang J, Gao H. Association of TNFAIP8 gene polymorphisms with endometrial cancer in northern Chinese women. Cancer Cell Int. 2019;19:105.

22. Wang J, Gao H, Liu G, Gu L, Yang C, Zhang F, Liu T. Tumor necrosis factor a-induced protein 8 expression as a predictor of prognosis and resistance in patients with advanced ovarian cancer treated with neoadjuvant chemotherapy. Hum Pathol. 2018;82:239-48. 
23. Liu T, Xia B, LuY, Xu Y, Lou G. TNFAIP8 overexpression is associated with platinum resistance in epithelial ovarian cancers with optimal cytoreduction. Hum Pathol. 2014:45(6):1251-7.

24. Odicino F, Pecorelli S, Zigliani L, Creasman WT. History of the FIGO cancer staging system. Int J Gynaecol Obstet. 2008;101(2):205-10.

25. Couch FJ, Wang X, McGuffog L, Lee A, Olswold C, Kuchenbaecker KB, et al. Genome-wide association study in BRCA1 mutation carriers identifies novel loci associated with breast and ovarian cancer risk. PLoS Genet. 2013:9(3):e1003212

26. Amankwah EK, Lin HY, Tyrer JP, Lawrenson K, Dennis J, Chornokur G, et al. Epithelial-mesenchymal transition (EMT) gene variants and epithelial ovarian cancer (EOC) risk. Genet Epidemiol. 2015;39(8):689-97.
27. Vigorito E, Kuchenbaecker KB, Beesley J, Adlard J, Agnarsson BA, Andrulis IL, et al. Fine-scale mapping at 9p22.2 identifies candidate causal variants that modify ovarian cancer risk in BRCA1 and BRCA2 mutation carriers. PLOS ONE. 2016;11(7):e0158801.

\section{Publisher's Note}

Springer Nature remains neutral with regard to jurisdictional claims in published maps and institutional affiliations.
Ready to submit your research? Choose BMC and benefit from:

- fast, convenient online submission

- thorough peer review by experienced researchers in your field

- rapid publication on acceptance

- support for research data, including large and complex data types

- gold Open Access which fosters wider collaboration and increased citations

- maximum visibility for your research: over $100 \mathrm{M}$ website views per year

At BMC, research is always in progress.

Learn more biomedcentral.com/submissions 